\title{
PERANCANGAN SISTEM KENDALI OTOMATIS PADA SMART HOME MENGGUNAKAN MODUL ARDUINO UNO
}

\author{
*Danny Kurnianto, Abdul Mujib Hadi, Eka Wahyudi \\ ST3 Telkom Purwokerto \\ Jln. D.I Panjaitan No.128 Purwokerto, Jawa Tengah, Indonesia \\ *Corresponding author, e-mail : dannykurnianto@st3telkom.ac.id
}

\begin{abstract}
Abstrak - Efisiensi, efektifitas dan penghematan energi listrik telah menjadi topik penelitian yang menarik banyak peneliti sekarang ini. Model teknologi telah banyak yang diusulkan untuk meningkatkan efektifitas dan hemat energi listrik bagi hajat hidup masyarakat. Salah satu contohnya adalah model teknologi Smart Home. Model Smart Home yang diusulkan pada penelitian ini dikendalikan secara terpusat oleh sebuah mikrokontroler Arduino Uno. Mikrokontroler mendeteksi output dari dua sensor magnetik yang terpasang di pintu masuk. Tanggapan mikrokontroler terhadap dua output sensor magnetik berupa kendali terhadap lampu ruang, kipas angin, perangkat pengusir nyamuk dan tampilan LCD. Sistem akan bekerja otomatis ketika seseorang masuk ke dalam rumah. Lampu ruang akan menyala secara otomatis, kipas angin akan bekerja sesuai dengan kondisi suhu ruang dan perangkat pengusir nyamuk akan bekerja secara otomatis. Hasil pengujian menunjukkan bahwa model Smart Home yang diusulkan dapat bekerja dengan baik sesuai perancangan dengan tingkat keberhasilan sebesar $100 \%$.
\end{abstract}

\section{Kata Kunci : Smart Home, Kendali Otomatis berbasis Arduino, Arduino, Mikrokontroler}

\begin{abstract}
Efficiency, effectiveness and electrical energy saving have become topics of research that attracts many researchers today. Model of technology has been widely proposed to improve effectiveness and energy saving for the livelihood of the peoples. One of example is a model of a Smart Home technology. Smart Home models proposed in this research is controlled centrally by an Arduino Uno microcontroller. Microcontroller detect output from the two magnetic sensors installed in the entrance. Microcontroller response to the two outputs of magnetic sensors in the form of control of room lighting. fan, mosquito repellent and LCD. The system will work automatically when someone inside the house. Room lights will turn on automatically, the fan will work in accordance with the room temperature conditions and mosquito repellent device will work automatically. The test results show that the proposed model of a Smart Home can work well according design with a success rate of $100 \%$.
\end{abstract}

\section{Keywords : Smart Home, Automatically control based on Arduino, Arduino, Microcontroller}

Copyright $\odot 2016$ JNTE. All rights reserved

\section{PENDAhULUAN}

Di era perkembangan teknologi analog, pada umumnya perangkat-perangkat listrik dikendalikan secara manual oleh pengguna. Seseorang harus menghidupkan dan mematikan sakelar secara langsung yang terhubung ke perangkat listrik tersebut. Terkadang, ada beberapa perangkat listrik yang dijumpai masih hidup ketika tidak digunakan, hal ini dapat disebabkan oleh kelalaian pengguna untuk mematikan perangkat listrik tersebut. Jika jumlah perangkat listrik yang berada di dalam suatu rumah cukup banyak, maka akan sangat tidak efektif dan tidak nyaman untuk mematikan dan menghidupkan perangkat-perangkat listrik tersebut secara manual. Penggunaan energi listrik dari perangkat-perangkat tersebut juga akan tidak efisien (boros energi listrik).

Perkembangan teknologi digital yang pesat ikut mendorong perkembangan teknologi komputer. Sekarang ini, banyak perangkatperangkat listrik yang bekerja secara terintegrasi dengan sistem komputer. Hal ini tentunya akan sangat membantu pekerjaan manusia dalam mengoperasikan perangkat listrik tersebut. Salah satu penelitian yang sedang berkembang sekarang ini adalah mengenai Smart Home. Perangkat Smart Home adalah sebuah perangkat yang memiliki sistem otomatisasi sangat canggih untuk mengendalikan lampu dan suhu, perangkat multi media untuk memantau dan 
menghidupkan sistem keamanan yang terhubung dengan pintu atau jendela dan beberapa fungsi yang lainnya [1].

Smart Home memiliki beberapa manfaat seperti memberikan kenyamanan yang lebih baik, keselamatan dan keamanan yang lebih terjamin, dan menghemat penggunaan energi listrik [2]. Dengan menerapkan perangkat Smart Home di rumah atau perkantoran, perangkat-perangkat listrik akan dapat bekerja secara otomatis sesuai dengan kebutuhan pengguna. Pengguna juga dapat memantau dan mengendalikan perangkatperangkat listrik di dalam rumah dari jarak jauh melalui suatu saluran komunikasi seperti melalui jaringan internet, Wi-Fi atau bluetooth.

Berdasarkan latar belakang di atas, maka pada penelitian ini akan dirancang suatu model sistem Smart Home yang bekerja secara otomatis dengan menggunakan modul Arduino Uno sebagai pusat pengendali. Parameter yang akan dikendalikan adalah suhu, pencahayaan dan alat pengusir nyamuk.

\section{TINJAUAN PUSTAKA}

Penelitian mengenai Smart Home sedang menjadi tranding topic akhir-akhir ini. Hal ini dikarenakan penggunaan energi listrik penduduk bumi yang semakin besar sedangkan sumber energi listri terbatas. Disamping itu, gaya hidup manusia sekarang yang mengharuskan segala sesuatu serba cepat dan nyaman menjadikan penelitian ini menjadi semakin menarik.

Penelitian mengenai model Smart Home dengan sistem yang dapat merespon beberapa aktifitas manusia, yaitu dengan memberikan action seperti menghidupkan dan mematikan perangkat listrik secara otomatis dan terkomputerisasi. Beberapa penelitian tersebut seperti.

Model Smart Home dengan menggunakan smart card berbasis RFID sebagai pengunci elektronis [3]. Saat smart card dipindai oleh sistem, maka sistem akan segera merespon dengan memonitor beberapa parameter seperti membuka pintu, tirai dan lampu pijar. Sensorsensor dipasang untuk memonitor kondisi pintu, tirai dan lampu pijar. Kendali logika Fuzzy digunakan untuk mengaktifkan aktuatoraktuator pada pintu, tirai dan lampu pijar.

Pintu elektronik menggunakan password yang diketikkan pada keypad diusulkan pada model Smart Home ini [4]. Sistem akan memantau parameter lampu pijar dan atap jemuran. Jika sensor gerak mendeteksi adanya pergerakan manusia maka lampu akan hidup. Demikian juga jika sensor air mendeteksi adanya hujan, maka atap jemuran akan menutup. Hasil pengujian menunjukkan bahwa sistem telah dapat bekerja secara otomatis sesuai dengan perencanaan.

Model Smart Home selanjutnya adalah perangkat shading device yang berfungsi untuk melindungi rumah dari sinar matahari secara langsung [5]. Perangkat ini secara otomatis akan menutup dan membuka jendela rumah berdasarkan parameter nilai cahaya, nilai suhu dan kelembaman pada ruangan. Sensor SHT11 sebagai sensor suhu dan kelembaban, sensor DT-Light sebagai sensor cahaya. Hasil pengujian menunjukkan bahwa perangkat ini sudah dapat bekerja secara otomatis berdasarkan tiga parameter diatas.

Desain sistem pengendali lampu dan perangkat listrik yang diusulkan berfungsi untuk meniru keberadaan penghuni rumah saat rumah dalam keadaan kosong [6]. Sistem ini berbasis Arduino, RTC, interface perantara dengan perangkat listrik. Sistem bekerja dengan membangkitkan bilangan acak setiap 15 menit yang terkait dengan setiap perangkat listrik. Perangkat listrik akan hidup dan mati selama jeda waktu yang telah ditetapkan. Konsumsi daya listrik dari sistem per hari sebesar 0,42.

Penelitian pada model Smart Home untuk memantau dan mengendalikan perangkat listrik dari jarak jauh menggunakan suatu saluran komunikasi diantaranya seperti.

Model Smart Home dengan Rasberry Pi sebagai pengendali pusat [7]. Rasberry Pi mengendalikan beberapa perangkat listrik di dalam rumah berdasarkan perintah jarak jauh yang dikirimkan oleh pengguna melalui sebuah smartphone berbasis aplikasi android. Komunikasi data antara smartphone dengan Rasberry Pi mengunakan komunikasi wireless yang bersifat lokal. Kelemahan model ini adalah beroperasi secara semi otomatis karena masih melibatkan peran manusia dalam mengontrol perangkat listrik di dalam rumah. Penggunaan komunikasi wireless juga diterapkan pada penelitian yang menggunakan perangkat Xbee S6 [8]. Kelemahan dari perangkat ini adalah dibatasi oleh jarak, karena jarak maksimum XBee S6 hanya sekitar 9 meter saja. Selain Xbee, penelitian lain yang memakai perangkat 
wireless seperti internet shield digunakan untuk mengirimkan data energi listrik dari Arduino ke web server secara real time [9]. Parameter listrik yang dikirimkan seperti Vrms, Irms,daya nyata dan faktor daya. Kelebihan dari sistem ini adalah penggunaan energi listrik dapat dipantau melalui suatu web secara real time.

Pengembangan penelitian selanjutnya terletak pada komunikasi data yang sudah menggunakan jaringan internet [10]. Pemantauan dan pengendalian perangkat listrik dapat dilakukan menggunakan smartphone melalui jaringan internet. Komputer server sebagai pengendali pusat yang menghubungkan komunikasi data antara smartphone dengan perangkat mikrokontroler. Peran pengguna atau manusia masih terlihat pada model Smart Home ini.

Selain menggunakan komunikasi wireless dan jaringan internat untuk mengendalikan perangkat listrik jarak jauh, ada beberapa penelitian yang menggunakan jaringan TCP/IP [11] dan komunikasi Bluetooth pada smartphone [12]. Kelemahan model komunikasi ini adalah hanya bersifat lokal saja atau terbatas jaraknya.

\section{METODOLOGI}

Pada penelitian ini digunakan metode dengan merancang model Smart Home yang kemudian diuji setiap sub sistem dari model tersebut. Pada bagian akhir setelah pengujian sub sistem, dilakukan pengujian model sistem secara keseluruhan untuk melihat tingkat keberhasilan dari model sistem Smart Home yang dirancang.

\subsection{Alat dan Bahan}

Berikut ini adalah alat dan bahan yang digunakan pada penelitian perancangan model Smart Home.

1. Software Proteus

2. Modul Arduino Uno

3. Sensor magnetic Reed Switch

4. Sensor suhu LM35

5. LCD

6. Speaker

7. Relay

\subsection{Diagram Blok Sistem}

Pada Gambar 1 ditunjukkan diagram blok sistem model Smart Home yang diusulkan. Input dari sistem terdiri dari sensor magnetik yang bertindak sebagai switch otomatis. Sensor magnetik dipasang pada pintu masuk sehingga saat sensor aktif maka akan menghidupkan lampu dan gelombang ultrasonik (keluar melalui speaker).

Sensor suhu digunakan untuk memantau kondisi suhu ruang, jika suhu terlalu panas maka sistem akan menyalakan kipas angin secara otomatis. Serial monitor pada Arduino digunakan untuk memberikan pesan yang akan ditampilkan di LCD.

Pada sisi output, terdapat beberapa komponen seperti Speaker untuk mengeluarkan gelombang ultrasonik, lampu pijar yang bekerja saat sensor magnetik aktif, kipas angin yang bekerja saat suhu di dalam ruang panas, dan LDC untuk menampilkan data suhu ruang dan pesan. Modul Arduino Uno digunakan sebagai pusat pengolah data dan kendali sistem.

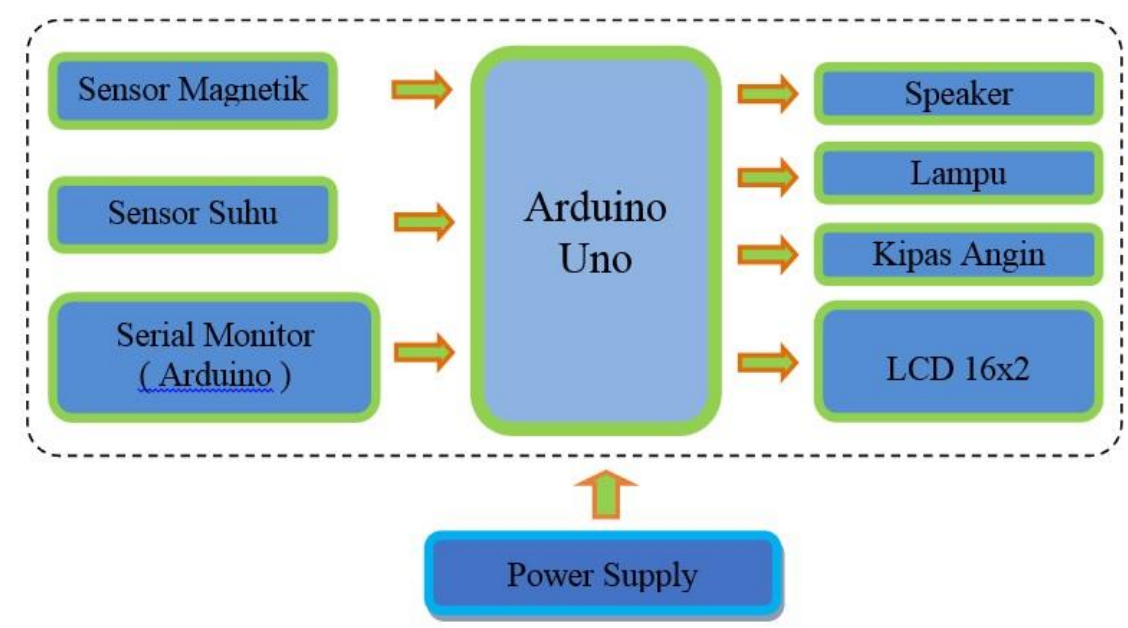

Gambar 1. Diagram Blok Sistem Model Smart Home 


\subsection{Perancangan Perangkat Keras}

\subsubsection{Antarmuka Sensor Magnetik}

Sensor magnetik yang digunakan berupa dua buah reed switch buluh getar yang dipasang di pintu masuk dan magnetik ID. Pada kondisi ON, sensor akan memberika logika "0" pada Arduino dan sebaliknya jika kondisi OFF, sensor akan memberikan logika "1" pada Arduino. Output dari kedua sensor terhubung dengan pin 13 dan 8 pada Arduino. Pada Gambar 2 ditunjukkan rangkaian antarmuka sensor magnetik dengan Arduino uno. Pada Tabel 1 ditunjukkan kondisi logika yang diharapkan dari kedua sensor magnetik.

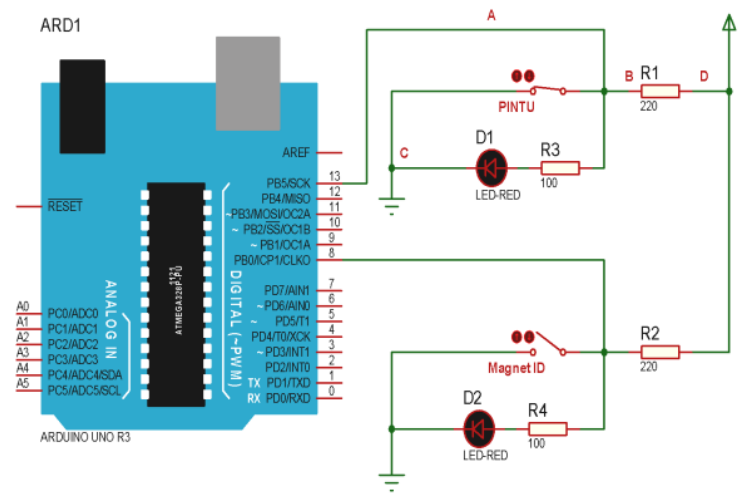

Gambar 2. Antarmuka sensor magnetik

Tabel 1. Kondisi logika pada dua sensor magnetik

\begin{tabular}{|c|c|c|}
\hline $\begin{array}{c}\text { Pintu } \\
\text { (logika) }\end{array}$ & $\begin{array}{c}\text { ID Magnet } \\
\text { (logika) }\end{array}$ & $\begin{array}{c}\text { Logika Output } \\
\text { (logika) }\end{array}$ \\
\hline Tertutup (0) & Tidak Terpasang (0) & LOW (0) \\
\hline Tertutup (0) & Terpasang (1) & HIGH (1) \\
\hline Terbuka (1) & Tidak Terpasang (0) & HIGH (1) \\
\hline Terbuka (1) & Terpasang (1) & HIGH (1) \\
\hline
\end{tabular}

\subsubsection{Antarmuka Sensor Suhu}

Sensor suhu yang digunakan pada penelitian ini adalah LM35 dengan sensitifitasnya sebesar $10 \mathrm{mV} /{ }^{\circ} \mathrm{C}$, artinya setiap kenaikan suhu sebesar $1^{\circ} \mathrm{C}$ maka terjadi perubahan tegangan sebesar $10 \mathrm{mV}$ dengan arus sebesar $60 \mu \mathrm{A}$. Sensor suhu digunakan untuk memantau kondisi suhu di dalam ruang. Jika suhu ruang mencapai nilai lebih dari $27^{\circ} \mathrm{C}$, maka mikrokontroler akan mengaktifkan relay (on) yang terhubung dengan kipas angin. Saat relay on maka kipas angin akan berputar. Jika suhu berada dibawah $27^{\circ} \mathrm{C}$, maka mikrokontroler akan mematikan relay dan kipas berhenti berputar. Pada Gambar 3 ditunjukkan antarmuka sensor suhu dengan modul Arduino uno. Output sensor LM35 dihubungkan dengan port $\mathrm{C}$ pin 0 (PC0).

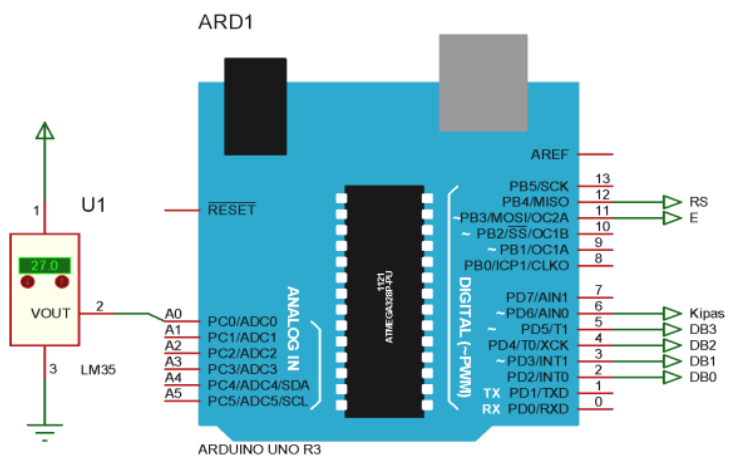

Gambar 3. Antarmuka sensor suhu

\subsubsection{Antarmuka Serial Monitor (Arduino)}

Komunikasi serial pada modul Arduino menggunakan port PD0 dan PD1 atau Rx Tx. Didalam proses pengiriman data secara serial, Arduino juga mempunyai aplikasi untuk pengiriman tersebut (Serial Monitor). Dengan memanfaatkan aplikasi serial, pengiriman pesan dari komputer untuk ditampilkan pada LCD dapat dilakukan dengan baik. Pada Gambar 4 ditunjukkan antarmuka serial monitor pada Arduino.

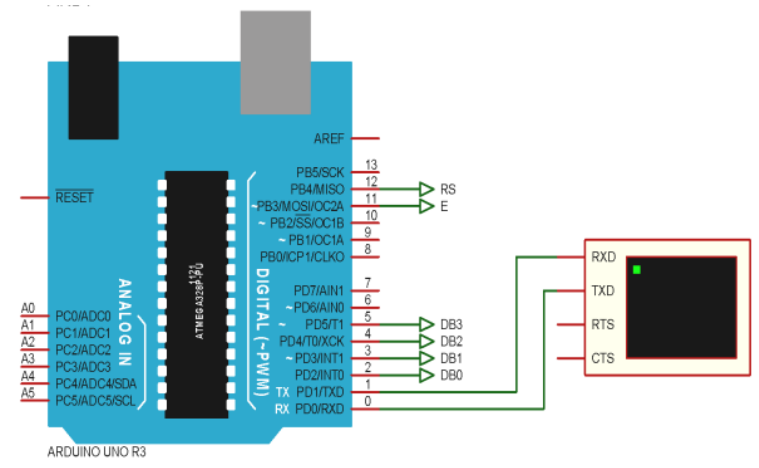

Gambar 4. Antarmuka serial monitor Arduino

\subsubsection{Antarmuka Speaker}

Speaker pada model Smart Home yang diusulkan digunakan untuk mengeluarkan gelombang elektromagnetik berupa gelombang bunyi dengan frekuensi tertentu. Pada Arduino terdapat library untuk pembangkitan frekuensi dengan karaktristik tertentu. Untuk Arduino uno fungsi pembangikat frekuensi terletak pada pin 
10 dan 9 digital dengan tanpa konfigurasi awal. Library tone $A C$ pada arduino merupakan library additional. Secara default software Arduino IDE ini tidak mengandung library toneAC. Oleh karena itu, library tersebut harus ditambahkan sendiri dengan mengunduh di website Arduino. Pada Gambar 5 ditunjukkan antarmuka Speaker dengan Arduino.

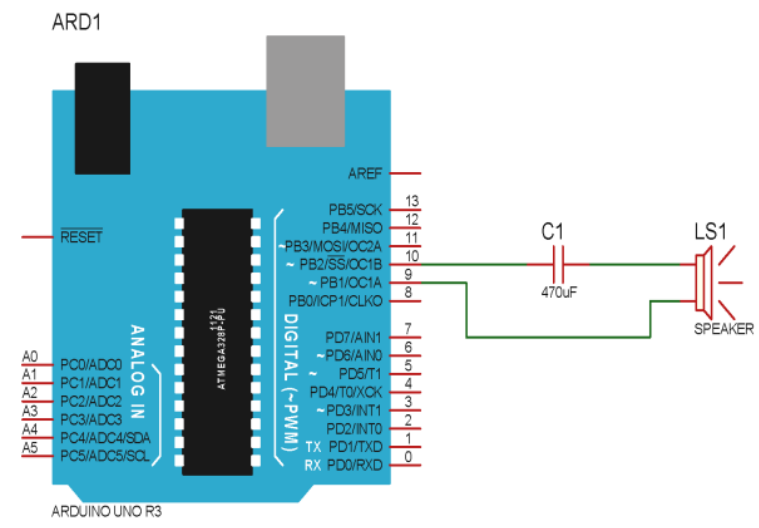

Gambar 5. Antarmuka Speaker dengan Arduino

\subsubsection{Antarmuka Driver Relay Lampu dan Kipas Angin}

Untuk mematikan dan menghidupkan lampu serta kipas angin, digunakan sebuah relay sebagai sakelar elektronik. Sebagai driver Relay, digunakan sebuah transistor tipe 2N3904 yang dioperasikan pada daerah kerja saturasi. Pada Gambar 6 ditunjukkan antarmuka driver Relay lampu dan kipas angin.

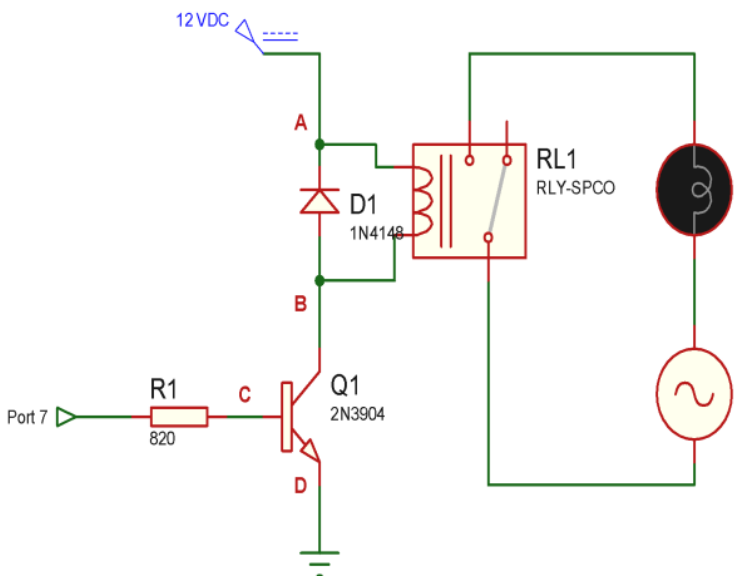

Gambar 6. Antarmuka driver relay lampu

Driver relay akan hidup jika pin 7 bernilai high " 1 " dan akan mati ketika logic low "0". Untuk menjadikan transistor 2N3904 bekerja pada daerah saturasi, maka arus basis (Ib) dan tegangan basis emitor (Vbe) harus diatur sesuai dengan nilai $\mathrm{Ib}$ saturasi sebesar $5 \mathrm{~mA}$ dan tegangan Vbe saturasi sebesar $900 \mathrm{mV}$.

$$
\begin{aligned}
\mathrm{Vs} & =\mathrm{I}_{\mathrm{B}} \times \mathrm{R}+\mathrm{V}_{\mathrm{BE}} \\
5 \mathrm{~V} & =5 \mathrm{~mA} \times \mathrm{R}+900 \mathrm{mV} \\
4,1 & =5 \mathrm{~mA} \times \mathrm{R} \\
\mathrm{R} & =4,1 / 5 \mathrm{~mA} \\
& =820 \Omega
\end{aligned}
$$

\subsubsection{Antarmuka LCD}

LCD digunakan untuk menampilkan karakter. Pada baris pertama digunakan untuk menampilkan data suhu ruang dan baris kedua digunakan untuk menampilkan pesan. Pada Gambar 7 ditunjukkan antarmuka LCD dengan Arduino.

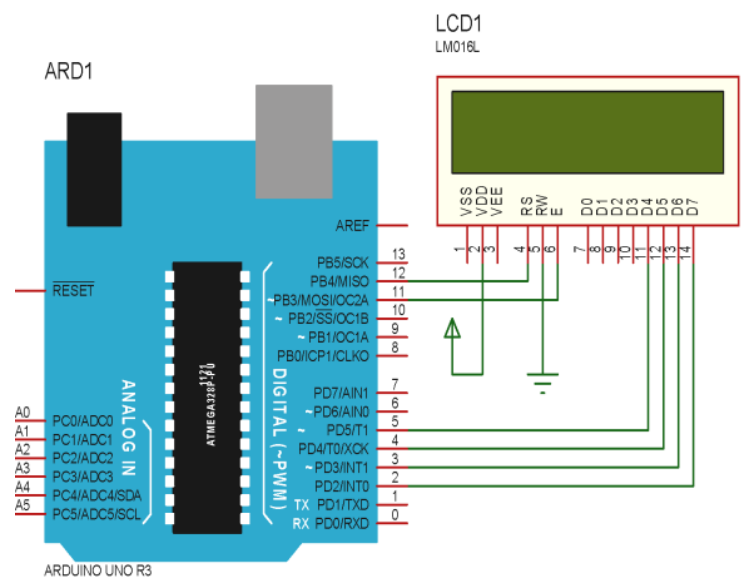

Gambar 7. Antarmuka LCD dengan Arduino

Pin 2 pada LCD terhubung dengan sumber tegangan dan pin 5 LCD terhubung dengan ground. Proses pengiriman data LCD menggunakan 4 bit serial bus D4-D7 yang terhubung dengan pin 2-5 pada Arduino. Untuk pengendalian pada LCD digunakan pin 4 (register select) yang terhubung dengan pin 12 Arduino dan pin 6 (enable) terhubung dengan pin 11 Arduino.

\subsection{Perancangan Perangkat Lunak}

Modul Arduino merupakan modul mikrokontroler yang didalamnya terdapat sebuah chip yang programmable. Sehingga, supaya modul Arduino dapat bekerja sesuai 


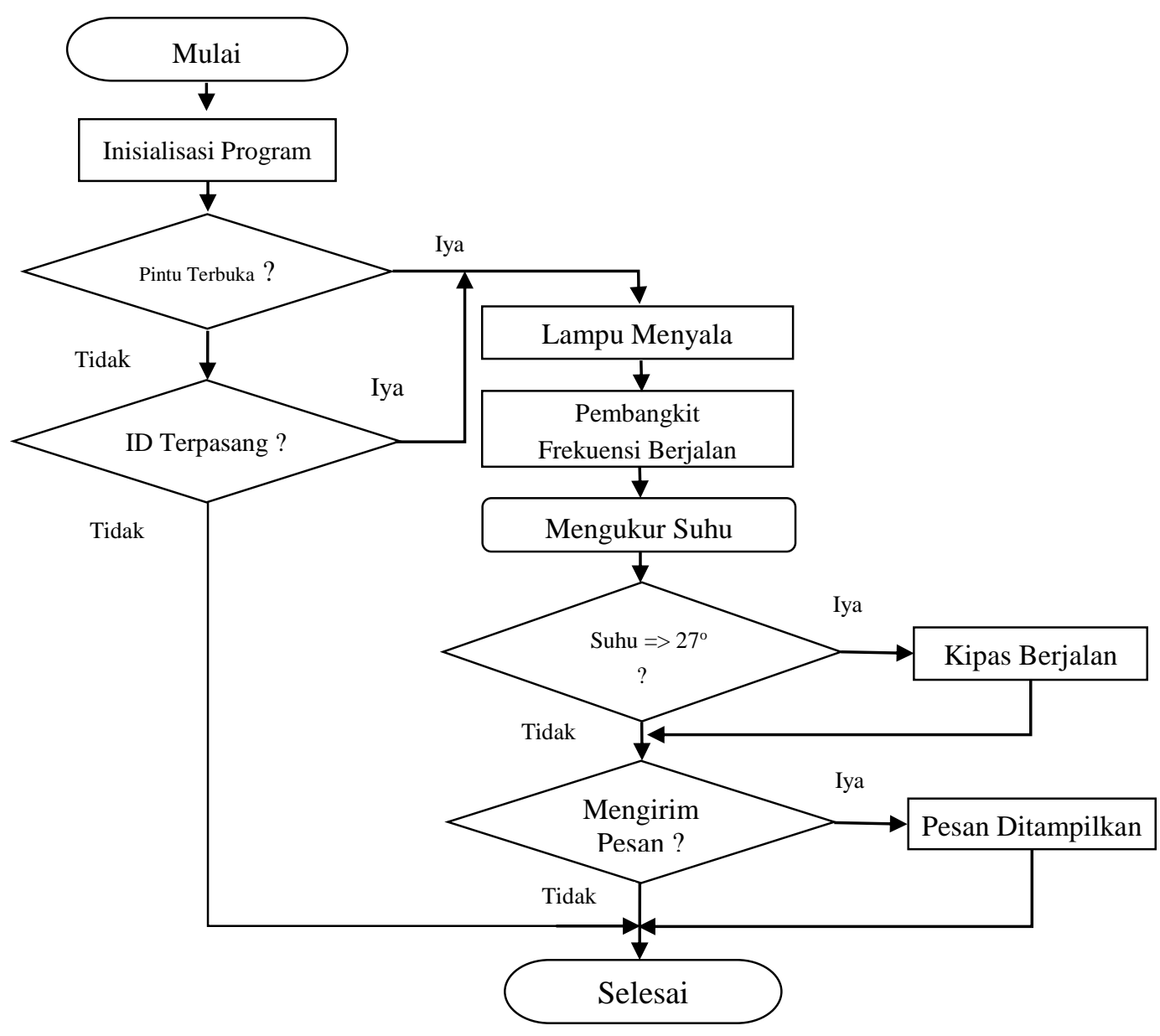

Gambar 8. Diagram alir sistem utama

dengan algoritma yang telah dirancang, chip mikrokontroler tersebut perlu diisi dengan sebuah program. Pada Gambar 8 ditunjukkan diagram alir (Flow chart) program utama dari model Smart Home yang diusulkan pada penelitian ini.

\section{HASIL DAN PEMBAHASAN}

\subsection{Pengujian Sensor Magnetik}

Pengujian sensor magnetik dilakukan untuk mengetahui operasi kerja sensor tersebut, serta untuk mengetahui operasi logika dari sensor. Rangkaian pengujian tegangan pull-up dan tegangan output sensor magnetik ditunjukkan pada Gambar 9. Pada rangkaian sensor magnetik, ketika kondisi reed switch dalam keadaan open circuit, maka tegangan sumber langsung masuk pada input Arduino (logika high), namun ketika reed switch dalam keadaan close circuit maka akan terjadi hubung singkat antara rangkaian sensor dengan tegangan sehingga tegangan input Arduino berlogika Low ( OV ).Pada Tabel 2 ditunjukkan hasil pengujian tegangan pull-up dan tegangan output sensor magnetik.

Tabel 2. Hasil pengujian tegangan pull-up dan tegangan output sensor magnetic

\begin{tabular}{|c|c|c|}
\hline $\begin{array}{c}\text { Sensor } \\
\text { Magnet }\end{array}$ & $\begin{array}{c}\text { Tegangan Pull } \\
\text { Down }\end{array}$ & $\begin{array}{c}\text { Tegangan } \\
\text { Keluar }\end{array}$ \\
\hline Terbuka & $1,41 \mathrm{~V}$ & $3,59 \mathrm{~V}$ \\
\hline Tertutup & $5 \mathrm{~V}$ & $0 \mathrm{~V}$ \\
\hline
\end{tabular}

Untuk menguji kondisi logika pada rangkaian dua sensor magnetik tersebut, dilakukan dengan menghubungkan 4 LED ke Arduino sebagai output kondisi logika pada 2 sensor. Pada Gambar 10 ditunjukkan rangkaian pengujian kondisi logika sensor. 


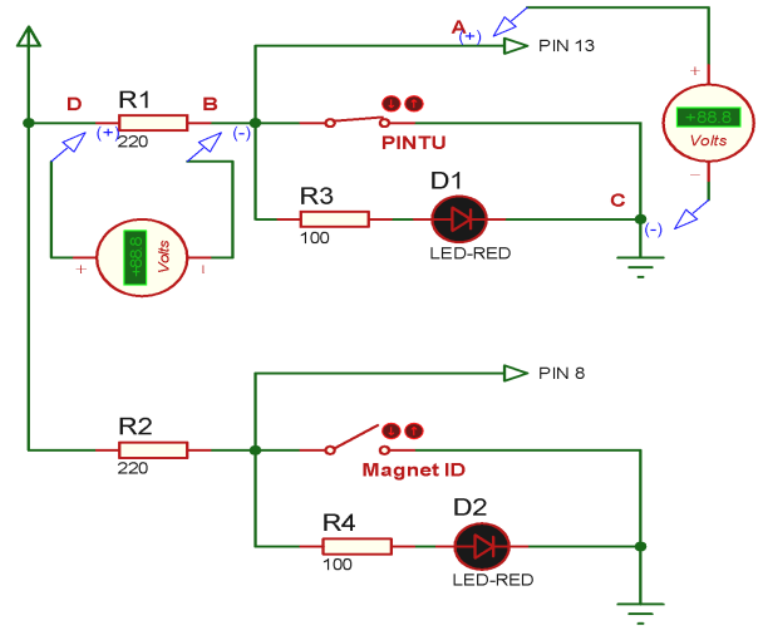

Gambar 9. Rangkaian pengujian tegangan pullup dan output sensor magnetic
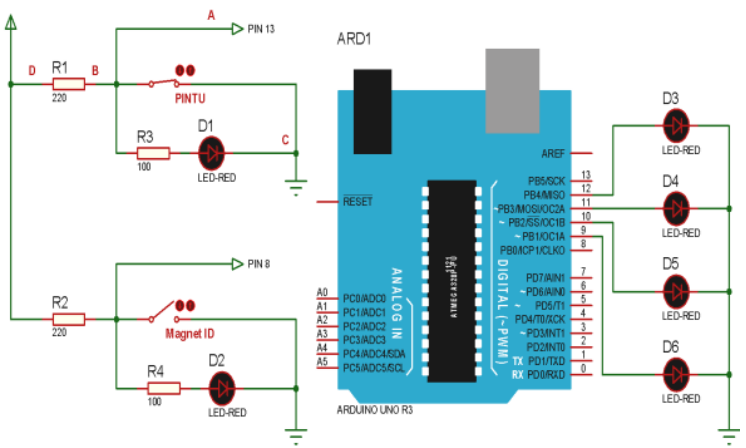

Gambar 10. Rangkaian pengujian kondisi logika pada 2 sensor

Hasil pengujian ditunjukkan pada Tabel 3 . Hasil pengujian menunjukkan bahwa output kondisi logika dari 2 sensor magnetik pada Tabel 3 sudah sesuai dengan yang direncanakan. Output kedua sensor magnetik akan diinterpretasikan oleh mikrokontroler dalam bentuk kondisi logika high ("1") atau low ("0") seperti yang ditunjukkan pada Tabel 1 .

\subsection{Pengujian Driver Relay}

Pada Gambar 11 ditunjukkan rangkaian pengujian driver relay untuk lampu dan kipas angin. Parameter yang diukur berupa tegangan basis emitor (VBE), tegangan kolektor emitor (VCE) dan tegangan relay. Hasil pengujian driver relay ditunjukkan pada Tabel 4.

Nilai yang terukur pada kaki basis sebesar $0,82 \mathrm{~V}$, namun seperti yang diketahui dari datasheet nilai tegangan maksimal pada kaki basis sebesar $0,85 \mathrm{~V}$ sehingga dapat diketahui ambang batas mendekati errornya seperti persamaan:

Persentase error $=(0,85-0,82 / 0,85) * 100 \%$ $=3,5 \%$

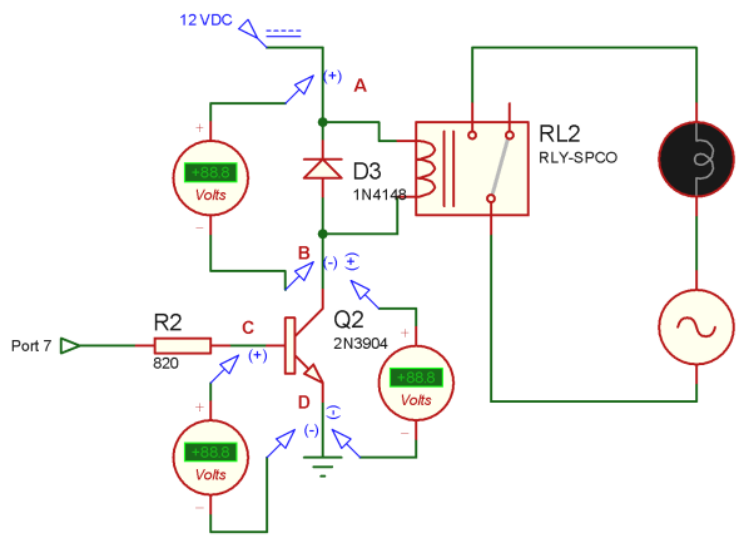

Gambar 11. Rangkaian pengujian driver relay

\subsection{Pengujian Speaker Untuk Suara Ultrasonik \\ Pengujian speaker dilakukan untuk} mengetahui lebar frekuensi yang dihasilkan dari speaker akibat pembangkitan frekuensi Arduino. Adapun rangkaian pengujian speaker dengan menggunakan oscilloscope seperti ditunjukkan pada Gambar 12.

Tabel 3. Hasil pengujian kondisi logika pada 2 sensor

\begin{tabular}{|c|c|c|c|c|c|}
\hline \multirow{2}{*}{$\begin{array}{c}\text { Pintu } \\
\text { (logika) }\end{array}$} & \multirow{2}{*}{ ID Magnet (logika) } & \multicolumn{4}{|c|}{ Output (logika) } \\
\cline { 3 - 6 } & & LED 1 & LED 2 & LED 3 & LED 4 \\
\hline Tertutup (0) & Tidak Terpasang (0) & Hidup (1) & Mati (0) & Mati (0) & Mati (0) \\
\hline Tertutup (0) & Terpasang (1) & Mati (0) & Hidup (1) & Mati (0) & Mati (0) \\
\hline Terbuka (1) & Tidak Terpasang (0) & Mati (0) & Mati (0) & Hidup (1) & Mati (0) \\
\hline Terbuka (1) & Terpasang (1) & Mati (0) & Mati (0) & Mati (0) & Hidup (1) \\
\hline
\end{tabular}


Tabel 4. Hasil pengujian driver relay

\begin{tabular}{|c|c|c|c|c|c|c|}
\hline \multirow{2}{*}{ Logic } & \multicolumn{2}{|c|}{ Tegangan Basis ( V $\left.\mathbf{B E}_{\mathbf{B E}}\right)$} & \multicolumn{2}{c|}{ Tegangan Transistor $\left(\mathrm{V}_{\mathbf{C E}}\right)$} & \multicolumn{2}{c|}{ Tegangan Relay } \\
\cline { 2 - 7 } & Terukur & Error & Terukur & Error & Terukur & Error \\
\hline HIGH & $0,82 \mathrm{~V}$ & $3,5 \%$ & $0,10 \mathrm{~V}$ & $50 \%$ & $11,9 \mathrm{~V}$ & $0,83 \%$ \\
\hline LOW & $0,5 \mathrm{~V}$ & $28,5 \%$ & $12 \mathrm{~V}$ & $0 \%$ & $0 \mathrm{~V}$ & $0 \%$ \\
\hline
\end{tabular}

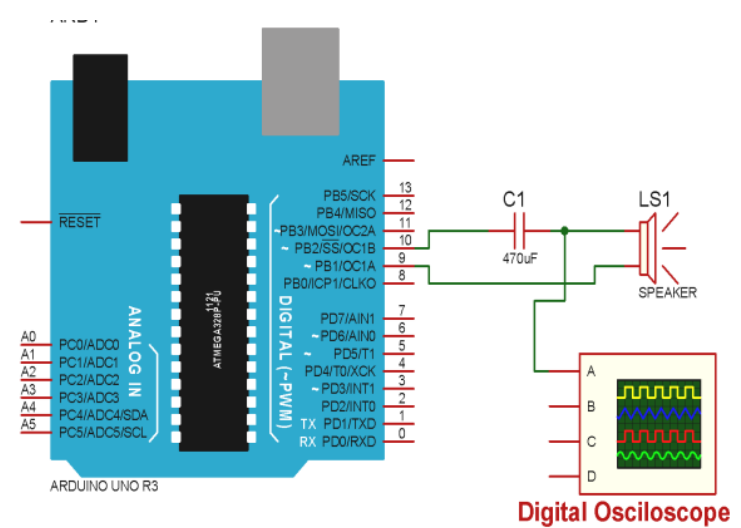

Gambar 12. Rangkaian pengujian Speaker

Pada Gambar 13 - 15 ditunjukkan hasil pengujian gelombang ultrasonik yang dikeluarkan oleh Speaker.

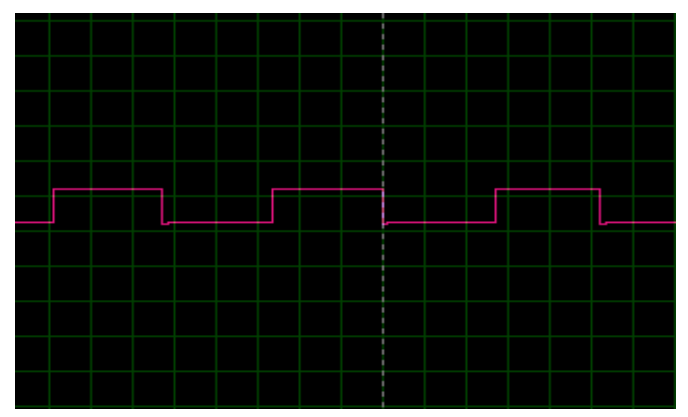

Gambar 13. Hasil gelombang ultrasonik pada $\mathrm{f}=38 \mathrm{KHz}$

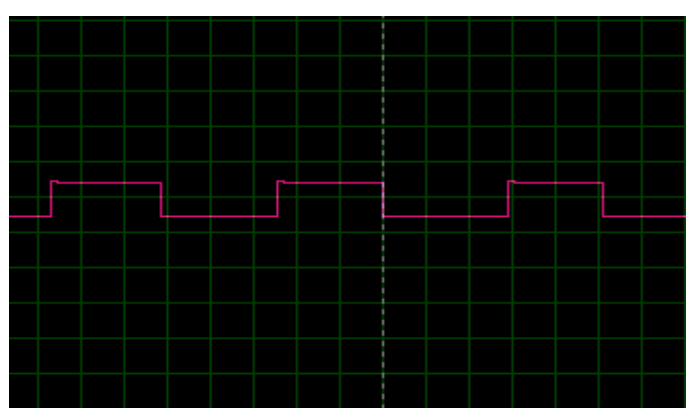

Gambar 14. Hasil gelombang ultrasonik pada $\mathrm{f}=39 \mathrm{KHz}$

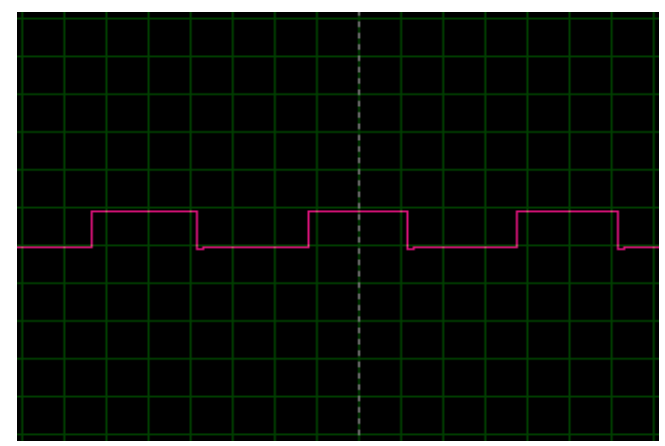

Gambar 15. Hasil gelombang ultrasonik pada $\mathrm{f}=40 \mathrm{KHz}$

Ket:

$$
\begin{aligned}
& \text { Time/div }: 5 \mathrm{uS} \\
& \text { Volt/div }: 500 \mathrm{mV}
\end{aligned}
$$

Frekuensi ultrasonik yang digunakan pada penelitian ini adalah frekuensi untuk mengusir nyamuk yang berada pada rentang $38-40 \mathrm{kHz}$.

Hasil perhitungan frekuensi dilihat dari keluaran oscilloscope seperti yang ditunjukkan pada Tabel 5.

Tabel 5. Hasil perhitungan frekuensi berdasarkan keluaran oscilloscope

\begin{tabular}{|c|c|c|c|}
\hline $\begin{array}{c}\text { Frekuensi } \\
\text { Ultrasonik }\end{array}$ & $\begin{array}{c}\text { Panjang } \\
\text { Gelombang } \\
\text { (kotak) }\end{array}$ & $\begin{array}{c}\text { Periode Per } \\
\text { Gelombang } \\
(\boldsymbol{\mu S})\end{array}$ & $\begin{array}{c}\text { Frekuensi } \\
(\mathbf{H z})\end{array}$ \\
\hline $38 \mathrm{kHz}$ & 5,26 & 26,3 & $38.022,81$ \\
\hline $39 \mathrm{kHz}$ & 5,12 & 25,6 & $39.062,50$ \\
\hline $40 \mathrm{kHz}$ & 5,00 & 25 & $40.000,00$ \\
\hline
\end{tabular}

Berdasakan Tabel 5, Frekuensi yang keluar dari speaker sudah sesuai dengan rancangan, yakni membangkitkan frekuensi ultrasonik dengan rentang frekuensi $38 \mathrm{kHz}-40 \mathrm{kHz}$.

\subsection{Pengujian Sensor Suhu}

Pada Gambar 16 ditunjukkan rangkaian pengujian Sensor suhu LM35. 


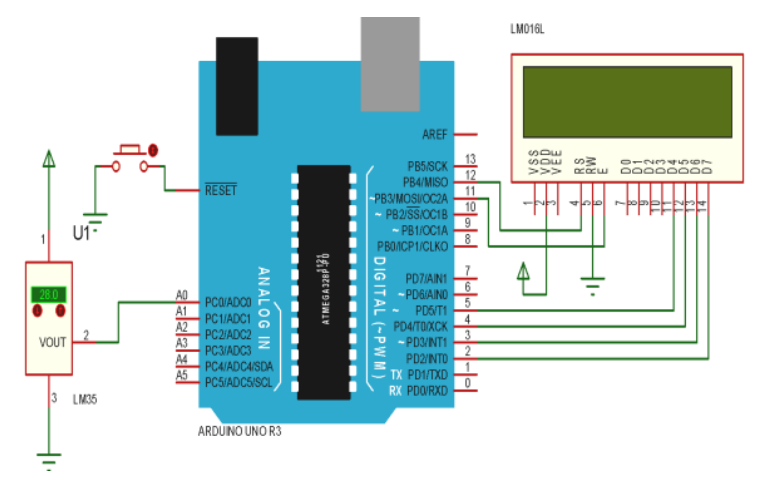

Gambar 16. Rangkaian pengujian sensor

Hasil pengujian tegangan output sensor LM35 ditunjukkan pada Tabel 6.

Tabel 6. Hasil pengujian tegangan output sensor LM35

\begin{tabular}{|c|c|c|c|}
\hline \multirow{2}{*}{$\begin{array}{c}\text { Suhu } \\
\text { Termometer }\end{array}$} & \multicolumn{2}{|c|}{ V $_{\text {out }}$ IC LM35 } & \multirow{2}{*}{$\begin{array}{l}\text { Error } \\
(\%)\end{array}$} \\
\hline & Seharusnya & Terukur & \\
\hline $29^{\circ} \mathrm{C}$ & $290 \mathrm{mV}$ & $304,6 \mathrm{mV}$ & 5,0 \\
\hline $30^{\circ} \mathrm{C}$ & $300 \mathrm{mV}$ & $310,3 \mathrm{mV}$ & 3,4 \\
\hline $31^{\circ} \mathrm{C}$ & $310 \mathrm{mV}$ & $324,4 \mathrm{mV}$ & 4,6 \\
\hline $32{ }^{\circ} \mathrm{C}$ & $320 \mathrm{mV}$ & $325,6 \mathrm{mV}$ & 1,7 \\
\hline $33^{\circ} \mathrm{C}$ & $330 \mathrm{mV}$ & $339,5 \mathrm{mV}$ & 2,8 \\
\hline $34{ }^{\circ} \mathrm{C}$ & $340 \mathrm{mV}$ & $344,6 \mathrm{mV}$ & 1,3 \\
\hline \multicolumn{3}{|c|}{ Rata-rata } & 3,13 \\
\hline
\end{tabular}

Hasil perbandingan output suhu thermometer dan output sensor suhu LM35 seperti yang ditunjukkan pada Tabel 7.

Tabel 7. Hasil perbandingan suhu thermometer dengan suhu sensor LM35

\begin{tabular}{|c|c|c|c|}
\hline $\begin{array}{c}\text { Suhu } \\
\text { Termometer }\end{array}$ & $\begin{array}{l}\text { Vout Sensor } \\
\text { LM35 }\end{array}$ & $\begin{array}{c}\text { Konversi } \\
\text { Suhu }\end{array}$ & $\begin{array}{l}\text { Error } \\
(\%)\end{array}$ \\
\hline $29^{\circ} \mathrm{C}$ & $304,6 \mathrm{mV}$ & $30,23^{\circ} \mathrm{C}$ & 11,9 \\
\hline $30^{\circ} \mathrm{C}$ & $310,3 \mathrm{mV}$ & $31,18^{\circ} \mathrm{C}$ & 11,3 \\
\hline $31{ }^{\circ} \mathrm{C}$ & $324,4 \mathrm{mV}$ & $32,23^{\circ} \mathrm{C}$ & 11,1 \\
\hline $32{ }^{\circ} \mathrm{C}$ & $325,6 \mathrm{mV}$ & $33,20^{\circ} \mathrm{C}$ & 10,6 \\
\hline $33^{\circ} \mathrm{C}$ & $339,5 \mathrm{mV}$ & $34,18^{\circ} \mathrm{C}$ & 10,2 \\
\hline $34{ }^{\circ} \mathrm{C}$ & $344,6 \mathrm{mV}$ & $35,16^{\circ} \mathrm{C}$ & 9,8 \\
\hline \multicolumn{3}{|c|}{ Rata-rata } & 10,81 \\
\hline
\end{tabular}

\subsection{Pengujian Penampil LCD}

Untuk menguji LCD dilakukan dengan cara menghubungkan modul Arduino dengan LCD dan komputer. Komputer digunakan untuk memberikan data karakter yang akan ditampilkan pada LCD. Pada Gambar 17 ditunjukkan rangkaian pengujian LCD.

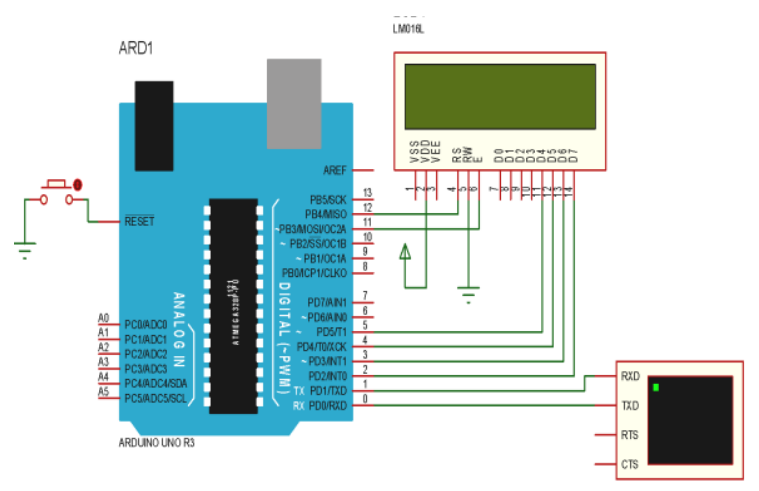

Gambar 17. Rangkaian pengujian LCD

Data karakter dikirimkan dari komputer ke Arduino menggunakan komunikasi serial pada baudrate 9600 bps. Hasil pengujian pengiriman karakter pada LCD ditunjukkan pada Tabel 8.

Berdasarkan hasil pengujian pengiriman data LCD pada Tabel 8, pengiriman data karakter hanya bisa dilakukan sebanyak 25 karakter setiap kali pengiriman karena lebar array yang tidak cukup. Jika melebihi dari 25 karakter maka kalimat akan rusak dengan muncul karakter terakhir pada awal scrolling dan karakternya sesuai karakter awal kalimat bukan karakter yang terakhir yang terpotong.

Berdasarkan hasil pengujian pengiriman data LCD pada Tabel 8, pengiriman data karakter hanya bisa dilakukan sebanyak 25 karakter setiap kali pengiriman karena lebar array yang tidak cukup. Jika melebihi dari 25 karakter maka kalimat akan rusak dengan muncul karakter terakhir pada awal scrolling dan karakternya sesuai karakter awal kalimat bukan karakter yang terakhir yang terpotong.

\subsection{Pengujian Modul Smart Home Keseluruhan \\ Pengujian modul Smart Home secara} keseluruhan dilakukan untuk mengetahui tingkat keberhasilan sistem dalam menjalankan fungsifungsi yang telah direncanakan. Beberapa parameter keluaran yang diamati adalah seperti kerja sensor magnetik, driver lampu dan kipas angin, gelombang ultrasonik untuk pengusir nyamuk, penampil LCD. Pada Tabel 9 ditunjukkan hasil pengujian modul Smart Home secara keseluruhan. 
Tabel 8. Hasil pengujian pengiriman karakter pada LCD

\begin{tabular}{|c|l|c|c|c|}
\hline No & \multicolumn{1}{|c|}{ KALIMAT } & KARAKTER & MUNCUL & SCROLL \\
\hline 1 & S & 1 & $\mathrm{~V}$ & TIDAK \\
\hline 2 & SE & 2 & $\mathrm{~V}$ & TIDAK \\
\hline 3 & SEL & 3 & $\mathrm{~V}$ & TIDAK \\
\hline 4 & SELA & 4 & $\mathrm{~V}$ & TIDAK \\
\hline 5 & SELAM & 5 & $\mathrm{~V}$ & TIDAK \\
\hline 6 & SELAMA & 7 & $\mathrm{~V}$ & TIDAK \\
\hline 7 & SELAMAT & 8 & $\mathrm{~V}$ & TIDAK \\
\hline 8 & SELAMAT<spasi> & 9 & $\mathrm{~V}$ & TIDAK \\
\hline 9 & SELAMAT D & 10 & $\mathrm{~V}$ & TIDAK \\
\hline 10 & SELAMAT DA & 11 & $\mathrm{~V}$ & TIDAK \\
\hline 11 & SELAMAT DAT & 12 & $\mathrm{~V}$ & TIDAK \\
\hline 12 & SELAMAT DATA & 13 & $\mathrm{~V}$ & TIDAK \\
\hline 13 & SELAMAT DATAN & 14 & $\mathrm{~V}$ & TIDAK \\
\hline 14 & SELAMAT DATANG & 15 & $\mathrm{~V}$ & TIDAK \\
\hline 15 & SELAMAT DATANG<spasi> & 16 & $\mathrm{~V}$ & TIDAK \\
\hline 16 & SELAMAT DATANG D & 17 & $\mathrm{~V}$ & BERULANG \\
\hline 17 & SELAMAT DATANG DI & 18 & $\mathrm{~V}$ & BERULANG \\
\hline 18 & SELAMAT DATANG DI<spasi> & 19 & $\mathrm{~V}$ & BERULANG \\
\hline 19 & SELAMAT DATANG DI W & 20 & $\mathrm{~V}$ & BERULANG \\
\hline 20 & SELAMAT DATANG DI WO & 21 & $\mathrm{~V}$ & BERULANG \\
\hline 21 & SELAMAT DATANG DI WOR & 22 & $\mathrm{~V}$ & BERULANG \\
\hline 22 & SELAMAT DATANG DI WORK & 23 & $\mathrm{~V}$ & BERULANG \\
\hline 23 & SELAMAT DATANG DI WORKS & & & \\
\hline
\end{tabular}

Tabel 9. Hasil pengujian modul Smart Home keseluruhan

\begin{tabular}{|c|l|c|c|}
\hline Aktivitas & \multicolumn{1}{|c|}{ Kondisi } & Hasil & Kesimpulan \\
\hline Step 1 & Pintu Terbuka, Sensor Magnet Terbuka & Sistem Aktif & Benar \\
\hline Step 2 & Pintu Tertutup, Sensor Magnet Tertutup, ID Card Terpasang & Sistem Aktif & Benar \\
\hline Step 3 & Lampu aktif, Ultrasonik aktif, Sensor Suhu aktif & Suhu > 30 ${ }^{\circ}$ C Kipas Aktif & Benar \\
\hline Step 4 & Suhu Meningkat, Data Pesan Ada & Info suhu dan pesan muncul & Benar \\
\hline Step 5 & Pintu Terbuka, Sensor Magnet Terbuka, ID Card tidak Terpasang & Sistem Aktif & Benar \\
\hline Step 6 & Pintu Tertutup, Sensor Magnet Tertutup, ID Card tidak Terpasang & Sistem Mati & Benar \\
\hline
\end{tabular}

Hasil pengujian seluruh modul Smart Home menunjukkan bahwa sistem yang dirancang telah dapat bekerja dengan baik sesuai dengan rancangan yang telah ditentukan. Arduino dapat merespon output dari sensor magnetik dan melakukan sejumlah fungsi secara otomatis seperti menyalakan lampu, menyalakan kipas angin dan lain-lain. Dapat dikatakan bahwa tingkat keberhasilannya telah mencapai $100 \%$.

\section{KESIMPULAN}

Kesimpulan yang dapat diambil dari penelitian "Perancangan Sistem Kendali Otomatis Pada Smart Home Menggunakan Modul Arduino Uno" adalah bahwa modul Smart Home yang dirancang telah dapat bekerja dengan baik dengan tingkat keberhasilan sebesar
100\%. Artinya bahwa sistem dapat bekerja secara otomatis ketika terdeteksi adanya seseorang yang masuk ke dalam rumah dengan mengaktifkan fungsi-fungsi sistem seperti menghidupkan lampu, menyalakan perangkat pengusir nyamuk dan menghidupkan kipas angin saat suhu mencapai nilai diatas $27^{\circ} \mathrm{C}$.

\section{DAFTAR PUSTAKA}

[1] D. Bregman, R. Blvd, and R. Lezion, "Smart Home Intelligence - The eHome that Learns," Int. J. Smart Home Smart Vol.4, No.4, vol. 4, no. 4, pp. 35-46, 2010.

[2] S. Kumar, "Ubiquitous Smart Home System Using Android Application," IJCNC, vol. 6, no. 1, pp. 33-43, 2014.

[3] A. Hanifah and I. Setiawan, "Makalah 
Seminar Tugas Akhir Aplikasi Smart Card Sebagai Pengunci Elektronis," Institusional Repos. UNDIP.

[4] H. Setiadi and Munadi, "Desain Model Smarthome System Berbasis Mikrokontroler," J. Tek. Mesin S-1, vol. 3, no. 2, pp. 138-142, 2015.

[5] M. dwisnanto Putro, "Perancangan Shading Device Pada Smart Home," Ejournal Tek. Elektro dan Komput., 2014.

[6] Zulfikar, Zulhelmi, and K. Amri, "Desain sistem kontrol penyalaan lampu dan perangkat elektronik untuk meniru keberadaan penghuni rumah," JNTE, vol. 5, no. 1, 2016.

[7] E. Fernando, "Automatisasi Smart Home Dengan Raspberry Pi Dan Smartphone Android," in Konferensi Nasional Ilmu Komputer (KONIK), 2014, pp. 1-5.

[8] Firdaus, A. A. Nuryono, and A. Sahroni, "Monitoring dan Kendali Lampu Berbasis Jaringan WiFi untuk Mendukung Smart Home," in Seminar Nasional ke - 9: Rekayasa Teknologi Industri dan Informasi, pp. 51-58.

[9] I. Dinata and W. Sunanda, "Implementasi Wireless Monitoring Energi Listrik Berbasis Web Database," JNTE, vol. 4, no. 1, pp. 83-88, 2015.

[10] F. Arifiyanto, W. A. Syafei, and M. Somantri, "Perancangan Prototype WebBased Online Smart Home Controlled By Smartphone," TRANSIENT, vol. 2, no. 3, 2013.

[11] H. I. Kirom, Sumardi, and Sudjadi, "Sistem Monitoring Kebocoran Gas LPG ( Liquefied Petroleum Gas ) Pada Smart Building Berbasis TCP / IP," TRANSIENT, vol. 2, no. 3, 2013.

[12] A. S. Rafika, M. S. H. Putra, and W. Larasati, "Smart Home Automatic Menggunakan Media Bluetooth Berbasis Mikrokontroller Atmega 328," CCIT, vol. 8, no. 3, pp. 215-222, 2015.

\section{Biodata Penulis}

Danny Kurnianto, lahir di Banyumas pada tanggal 19 April 1982. Jenjang pendidikan S1 ditempuh di jurusan Teknik Elektro Universitas Brawijaya, sedangkan jenjang S2 ditempuh di jurusan Teknik Elektro dan Teknologi Informasi Universitas Gadjah Mada. Penulis saat ini aktif sebagai dosen tetap di Prodi D3 Teknik Telekomunikasi Sekolah Tinggi Teknologi Telematika Telkom (ST3 Telkom) Purwokerto. 